\title{
MODEL PENGUKURAN KONSTRUKS ADOPSI INOVASI E-LEARNING
}

\author{
I Made Suarta dan I Ketut Suwintana
}

Politeknik Negeri Bali, Kampus Bukit Jimbaran, Badung, Bali, 80364, Indonesia

E-mail: i_md_suarta@yahoo.co.id

\begin{abstract}
Abstrak
Pemanfaatan e-learning di Politeknik Negeri Bali masih relatif baru. Sebagai inovasi baru, adopsi e-learning rentan terhadap penolakan. Dibutuhkan adanya informasi dalam mengurangi ketidakpastian dari adopsi e-learning tersebut. Tujuan penelitian adalah: (1) mendeskripsikan faktor-faktor adopsi inovasi e-learning; dan (2) menguji model pengukuran adopsi inovasi e-learning. Penelitian dilaksanakan menggunakan pendekatan kuantitatif dengan metode survei. Jumlah sampel sebanyak 130, dipilih dari staf pengajar yang pernah mengikuti pelatihan e-learning di setiap program studi di Politeknik Negeri Bali. Tingkat partisipasi responden (respons rate) mencapai $86,9 \%$. Data dianalisis secara deskriptif kuantitatif dan analisis faktor konfirmatori. Adopsi inovasi e-learning dijelaskan oleh lima karakteristik yaitu keunggulan relatif, kompatibilitas, kompleksitas, trialability, dan observability. Faktor keunggulan relatif mempunyai rerata tertinggi $(3,92)$, yang kemudian berturut-turut diikuti oleh trialability, observability, kompatibilitas, serta faktor kompleksitas mempunyai rerata terendah $(2,99)$. Berdasarkan nilai muatan faktor serta reliabilitas konstruk ditemukan bahwa variabel-variabel yang diamati mampu menjelaskan faktor-faktor yang menjadi karakteristik adopsi e-learning. Dengan demikian kelima karakteristik e-learning dinyatakan valid sebagai model pengukuran adopsi inovasi $e$ learning dengan nilai $\mathrm{p}=0,00224$ dan $\mathrm{RMSEA}=0,060$.
\end{abstract}

Kata-kata kunci: model pengukuran, adopsi, inovasi, e-learning

\begin{abstract}
The e-learning usage in Bali State Polytechnic is relatively new. As a new innovation, adoption of e-learning is vulnerable to rejection. It takes information to reduce uncertainty the adoption of e-learning. The research objectives are: (1) describe the adoption factors of e-learning innovation; and (2) confirmatory tests of the adoption e-learning innovation construct. The research was conducted using a quantitative approach with a survey method. Sample size are 130, representing of faculty members in each study program Bali State Polytechnic. The response rate in this study was $86.9 \%$. Data were analyzed by descriptive quantitative and confirmatory factor analysis. Adoption of e-learning innovations described by five characteristics: relative advantage, compatibility, complexity, trialability, and observability. Relative advantage has the highest average (3.92), followed by trialability, observability, compatibility, and complexity has the lowest average (2.99). Based on loading factor and constructs reliability, the observed variables are able to explain the factors that characterize adoption of e-learning. Thus, five characteristics e-learning is valid as a measurement model adoption of e-learning innovation with $p$-value $=0.00224$ and RMSEA $=0.060$.
\end{abstract}

Keywords: measurement model, adoption, innovation, e-learning

\section{Pendahuluan}

Perkembangan teknologi informasi dan komunikasi (TIK) dewasa ini memungkinkan banyak hal yang bisa dilakukan. TIK telah menjadi alat utama pada dunia pendidikan saat ini [1], tidak saja dimanfaatkan untuk mendukung proses belajar mengajar, namun juga untuk meningkatkan manajemen pengelolaan dan administrasi pendidikan [2], [3], [4].

E-learning merupakan salah satu aspek penerapan TIK dalam bidang pendidikan [5]. Menurut Šumak, et al. [6] e-learning berorientasi pada pemanfaatan teknologi informasi untuk 
memenuhi kebutuhan pembelajaran saat ini. $E$ learning memungkinkan orang belajar setiap saat di setiap tempat, dengan meminimalisasi kehilangan waktu. E-learning muncul sebagai solusi pembelajaran yang dapat diadopsi oleh siswa/mahasiswa sesuai dengan kebutuhannya yang beragam.

Pemanfaatan e-learning dilakukan melalui proses difusi dan adopsi. Menurut Rogers [7], difusi adalah proses yang terjadi pada suatu waktu dan memiliki lima tahapan yaitu: pengetahuan (knowledge), persuasi (persuasion), keputusan (decision), implementasi (implementation), dan konfirmasi (confirmation). Salah satu tahapan penting dalam proses mengadopsi suatu inovasi adalah tahapan persuasi atau pembentukan sikap.

Strategi mengadopsi dan memanfaatkan $e$ learning secara efektif merupakan isu penting bagi administrator pendidikan di seluruh dunia [8]. Pemanfaatan e-learning di Politeknik Negeri Bali masih relatif baru, yakni sejak tahun 2009. Sebagai inovasi baru, proses adopsi e-learning rentan terhadap penolakan. Banyak dosen dan mahasiswa yang tidak memiliki pengetahuan dan keterampilan untuk memanfaatkan e-learning secara efektif. Karena itu, dibutuhkan adanya informasi dalam mengurangi ketidakpastian dari adopsi e-learning tersebut.

Banyak faktor yang telah teridentifikasi berpengaruh terhadap adopsi e-learning. Faktorfaktor tersebut terkait dengan teknis, sistem, manusia, instruktur, dan faktor budaya [9]. Karakteristik inovasi e-learning, seperti yang dirasakan oleh para staf pengajar dan mahasiswa, menentukan laju adopsi. Rogers [7] menyebutkan keberhasilan dari suatu inovasi dapat dievaluasi dengan menggunakan lima karakteristik inovasi yaitu: keunggulan relatif, kompatibilitas, kompleksitas, trialability, dan observability. Ketika suatu inovasi dianggap oleh pengguna memiliki keunggulan relatif lebih besar, kompatibilitas, trialability, observability, dan kurang kompleks, inovasi tersebut akan diadopsi lebih cepat.

Keunggulan relatif adalah derajat di mana suatu inovasi dianggap lebih baik daripada inovasi yang digantikan [7]. Jika teknologi yang akan di adopsi menyediakan beberapa jenis peningkatan efektivitas atau efisiensi, maka orang cenderung untuk mengadopsi teknologi baru tersebut. Keunggulan relatif dari adopsi suatu inovasi dapat dinyatakan dalam bentuk keuntungan ekonomi, prestise sosial, penurunan ketidaknyamanan, biaya investasi semakin rendah, penghematan waktu dan daya, serta imbalan atau manfaat lainnya. Menurut Bennett \& Bennett [10] dalam kaitannya dengan e-learning, keunggulan relatif dapat dilihat pada keunggulan pedagogis dari teknologi instruksional yang melebihi alat-alat pengajaran konvensional.

Kompatibilitas adalah derajat di mana suatu inovasi dianggap konsisten dengan nilai-nilai yang ada, pengalaman masa lalu, dan media dari pengadopsi potensial [7]. Dalam hubungannya dengan inovasi e-learning, kompatibilitas dapat dimaknai sebagai sejauh mana e-learning konsisten dengan nilai-nilai dalam proses pembelajaran yang ada, konsisten dengan pengalaman masa lalu dan media yang selama ini digunakan.

Kompleksitas adalah derajat di mana suatu inovasi dianggap sulit untuk dipahami dan digunakan [7]. Semakin kompleks suatu inovasi maka semakin sulit untuk dapat diadopsi. Agar kompleksitas tidak menjadi faktor penghambat dalam adopsi inovasi, adalah penting untuk mengembangkan program pelatihan yang relevan dengan kebutuhan pengguna. Penelitian Serow \& Zorowski [11] menunjukkan kompleksitas sering ditemukan berbanding terbalik dengan difusi dari suatu inovasi, sementara kesederhanaan, atau kemudahan penggunaan, membuat penerimaan yang lebih luas dan lebih cepat.

Trialability adalah derajat di mana suatu inovasi dapat diuji coba sebelum adopsi. Ide-ide baru yang melalui proses uji coba dapat diadopsi lebih cepat. Sedangkan observability adalah derajat di mana hasil suatu inovasi dapat diamati orang lain [7]. Jika inovasi memiliki tingkat observability yang tinggi, maka akan relatif mudah untuk belajar tentang inovasi tersebut dan menilai potensi keuntungan. Hal ini pada gilirannya dapat meningkatkan kemungkinan adopsi.

Penelitian Bennett \& Bennett [10] menunjukkan bahwa hambatan utama yang dihadapi guru dalam menggunakan TIK bukan pada keterbatasan sarana TIK dan dana, tetapi lebih pada kemauan dalam menggunakan TIK dan keyakinan manfaat TIK. Butler \& Sellbom [12] meneliti faktor-faktor yang mempengaruhi guru dalam mengadopsi teknologi baru dan hambatan mengajar yang muncul selama adopsi. Hasil penelitian menunjukkan, kepercayaan dalam teknologi telah diidentifikasi sebagai faktor yang paling penting dalam keputusan guru apakah akan mengadposi atau tidak. Pengetahuan tentang bagaimana suatu teknologi, kesulitan dalam belajar dan waktu yang diperlukan untuk belajar muncul sebagai faktor kedua yang paling penting dalam adopsi. Kesulitan menggunakan dukungan teknologi dan manajemen muncul sebagai faktorfaktor lain yang mempengaruhi adopsi. Jebeile \& Reeve [8] melaporkan temuan dari studi adopsi teknologi Web oleh guru. Hasil penelitian menunjukkan bahwa keuntungan relatif, 
kompatibilitas, visibilitas, kemudahan penggunaan, demonstrability hasil, dan trialability harus dipertimbangkan oleh kepala sekolah dalam usaha untuk meningkatkan penggunaan $e$ learning. Hasil penelitian Carter \& Belanger [13] menunjukkan keunggulan relatif dan kompatibilitas merupakan prediktor yang signifikan dalam mengukur niat untuk menggunakan suatu inovasi. Sementara itu, hasil penelitian Kalema, et al. [14] menunjukkan kompleksitas berpengaruh negatif terhadap prioritas siswa dalam menggunakan course management system.

Penelitian ini mengadaptasi teori adopsi inovasi [7] dalam konteks pendidikan di Politeknik Negeri Bali. Tujuan penelitian adalah: (1) mendeskripsikan faktor-faktor adopsi inovasi e-learning; dan (2) menguji model pengukuran adopsi inovasi e-learning. Hasil penelitian ini diharapkan dapat memberikan informasi kepada pimpinan dalam mengambil kebijakan pengembangan dan pemanfaatan e-learning di politeknik.

\section{Metodologi}

Penelitian dilaksanakan menggunakan pendekatan kuantitatif dengan metode survei. Populasi penelitian adalah seluruh staf dosen Politeknik Negeri Bali. Sampel penelitian ditentukan sebanyak 30\% dari populasi, yakni 130 responden. Sampel dipilih dari staf dosen tiap program studi yang pernah mengikuti pelatihan penggunaan e-learning. Tingkat partisipasi responden (respons rate) dalam penelitian ini mencapai $86,9 \%$.

Instrumen penelitian dikembangkan dan diadaptasi dari Davis et al. [15], Moore \& Benbasat [16], Thompson et al. [17], Taylor \& Todd [18], dan Karahanna et al. [19]. Berdasarkan referensi tersebut, karakteristik inovasi e-learning terdiri atas lima faktor yaitu: (1) keunggulan relatif, (2) kompatibilitas, (3) kompleksitas, (4) trialability, dan (5) observability. Pada setiap faktor dikembangkan variabel-variabel yang kemudian akan diuji validitasnya. Secara keseluruhan karakteristik inovasi e-learning terdiri atas 18 variabel. Pengukuran setiap variabel menggunakan skala Likert dengan lima alternatif pilihan yaitu sangat setuju, setuju, netral, tidak setuju, dan sangat tidak setuju. Bobot penyekoran adalah sangat setuju $=5$, setuju $=4$, netral $=3$, tidak setuju $=2$, dan sangat tidak setuju $=1$. Untuk pernyataan yang bersifat negatif, bobot penyekoran dilakukan secara terbalik.

Analisis data secara deskriptif kuantitatif, meliputi ukuran pemusatan (rerata) dan ukuran penyebaran (simpangan baku). Validasi faktor- faktor adopsi inovasi e-learning dilakukan menggunakan analisis faktor konfirmatori (confirmatory factor analysis). Analisis faktor konfirmatori juga disebut model pengukuran (measurement model) ditujukan untuk mengkonfirmasi variabel-variabel yang dikembangkan pada sebuah faktor. Analisis faktor konfirmatori dilakukan dengan bantuan program LISREL 8,51 for Windows. Penelitian ini menggunakan kriteria penerimaan standardized loading factor dari masing-masing variabel teramati $(\lambda) \geq 0,40$, $t$-value standardized solution $\geq 1.96$, Construct Reliability (CR) $\geq 0.70$ serta kriteria goodness-of-fit p-value yang semakin kecil dan $\mathrm{RMSEA} \leq 0,06$ [20].

\section{Hasil dan Pembahasan}

\section{Deskripsi Faktor-Faktor Adopsi Inovasi E- learning}

Deskripsi hasil penelitian disajikan dalam bentuk ukuran pemusatan (rerata) dan ukuran penyebaran (simpangan baku), serta interpretasi deskriptif dari variabel-variabel penelitian. Statistik deskriptif hasil penelitian disajikan pada Tabel I.

Karakteristik adopsi e-learning dicirikan oleh lima faktor yaitu: (1) keunggulan relatif, (2) kompatibilitas, (3) kompleksitas, (4) trialability, dan (5) observability. Faktor keunggulan relatif mempunyai rerata tertinggi yakni 3,92, kemudian berturut-turut diikuti oleh faktor trialability $(3,71)$, observability $(3,66)$, kompatibilitas $(3,53)$, serta faktor kompleksitas mempunyai rerata terendah yakni 2,99. Salah satu variabel dari keunggulan relatif yaitu "e-learning memudahkan pelaksanaan proses pembelajaran (KR1) memiliki rerata skor tertinggi $(4,08)$. Sementara itu, rerata skor terendah variabel $(2,70)$ didapat oleh "penggunaan e-learning membutuhkan persiapan yang lebih lama (TR3)" yang merupakan salah satu variabel dari faktor kompleksitas. Hasil ini memberikan gambaran bahwa suatu inovasi yang mempunyai keunggulan relatif lebih baik semakin mudah untuk diterima, sedangkan semakin kompleks suatu inovasi maka semakin sulit untuk dapat diadopsi.

Hasil-hasil statistik deskriptif ini sejalan dengan Rogers [7] bahwa suatu inovasi yang mempunyai keunggulan relatif lebih baik, kompatibel dengan teknologi maupun inovasi sebelumnya, dapat diujicobakan, dapat diamati hasilnya, serta kurang kompleks, maka inovasi tersebut akan diadopsi lebih cepat. Hal ini ditunjukkan oleh faktor keunggulan relatif yang mempunyai rerata skor tertinggi sedangkan faktor kompleksitas mempunyai rerata skor terendah. 
4 Journal of Information Systems, Volume 8, Issue 1, April 2012

TABEL I

STATISTIK DESKRIPTIF HASIL-HASIL PENELITIAN (N=113)

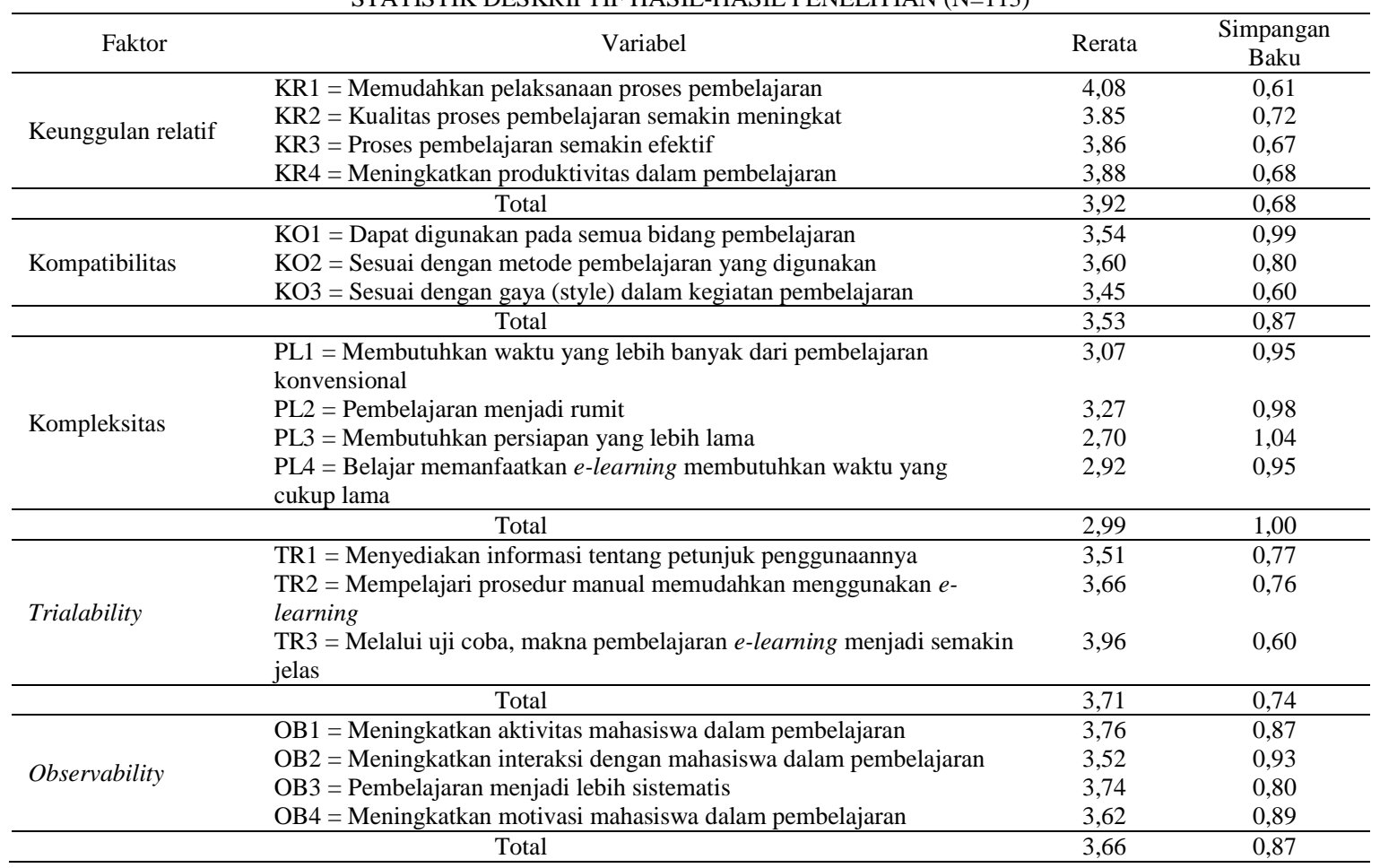

Semakin kompleks suatu inovasi maka semakin sulit untuk dapat diadopsi. Serow \& Zorowski [11] menyebutkan kompleksitas sering ditemukan berbanding terbalik dengan adopsi dari suatu inovasi. Hal ini juga sejalan dengan hasil korelasi antar faktor (Tabel II). Faktor-faktor adopsi e-learning menunjukkan adanya korelasi yang kuat $(>0,5)$, kecuali faktor kompleksitas $e$ learning menunjukkan korelasi yang lemah $(<0,5)$. Hal ini sesuai dengan variabel-variabel dalam faktor kompleksitas yang bersifat negatif, pernyataan dirumuskan secara terbalik. Rerata skor yang rendah serta adanya korelasi yang lemah, mengindikasikan e-learning tidak terlalu sulit untuk dipelajari. Dengan demikian proses adopsi e-learning menjadi semakin mudah.

TABEL II

KOEFISIEN KORELASI ANTAR FAKTOR

\begin{tabular}{cccccc}
\multicolumn{7}{c}{ KOEFISIEN KORELASI ANTAR FAKTOR } \\
\hline KR & 1,00 & KO & PL & TR & OB \\
\hline KO & 0,78 & 1,00 & - & - & - \\
PL & 0,28 & 0,19 & 1,00 & - & - \\
TR & 0,68 & 0,86 & 0,07 & 1,00 & - \\
OB & 0,73 & 0,73 & 0,16 & 0,91 & 1,00 \\
\hline
\end{tabular}

E-learning dilingkungan Politeknik Negeri Bali masih relatif baru. Namun demikian, hasil penelitian menunjukkan e-learning memudahkan pelaksanaan proses pembelajaran, proses pembelajaran menjadi semakin efektif, serta produktifitas pembelajaran semakin meningkat. Hasil ini mengindikasikan bahwa dosen sebagai pengguna melihat adanya manfaat yang lebih dari e-learning. Atau dengan kata lain, e-learning mempunyai keunggulan relatif yang lebih baik. Hal ini tentu akan mempercepat proses adopsi $e$ learning. Selain itu, belajar memanfaatkan $e$ learning dan mempersiapkan penggunaan $e$ learning ternyata tidak membutuhkan waktu yang lama. Hal ini dapat dimaknai bahwa e-learning tidak terlalu kompleks.

Hasil menarik lainnya menunjukkan bahwa $e$ learning masih kompatibel dengan metode pembelajaran yang selama ini digunakan oleh dosen. Sebagaimana dinyatakan oleh Rogers [7] kompatibilitas e-learning adalah derajat di mana suatu inovasi dianggap konsisten dengan nilainilai yang ada sebelumnya. E-learning juga mampu meningkatkan aktivitas mahasiswa dalam pembelajaran, serta membuat pembelajaran menjadi sistematis.

\section{Model Pengukuran Adopsi Inovasi E-learning}

Dalam penelitian ini, model pengukuran adopsi inovasi e-learning dihipotesiskan terdiri atas lima faktor yaitu: (1) keunggulan relatif (KR), (2) kompatibilitas (KO), (3) kompleksitas (PL), (4) trialability (TR), dan (5) observability (OB). Faktor-faktor ini diadaptasi dari Rogers [7]. Pada setiap faktor dikembangkan variabelvariabel yang diuji validitasnya menggunakan analisis faktor konfirmatori. Hasil analisis dalam bentuk standardized solution seperti pada Gambar 1. Rangkuman hasil analisis dan interpretasi atas validitas dan reliabilitas faktor-faktor adopsi $e$ learning disajikan pada Tabel III. 


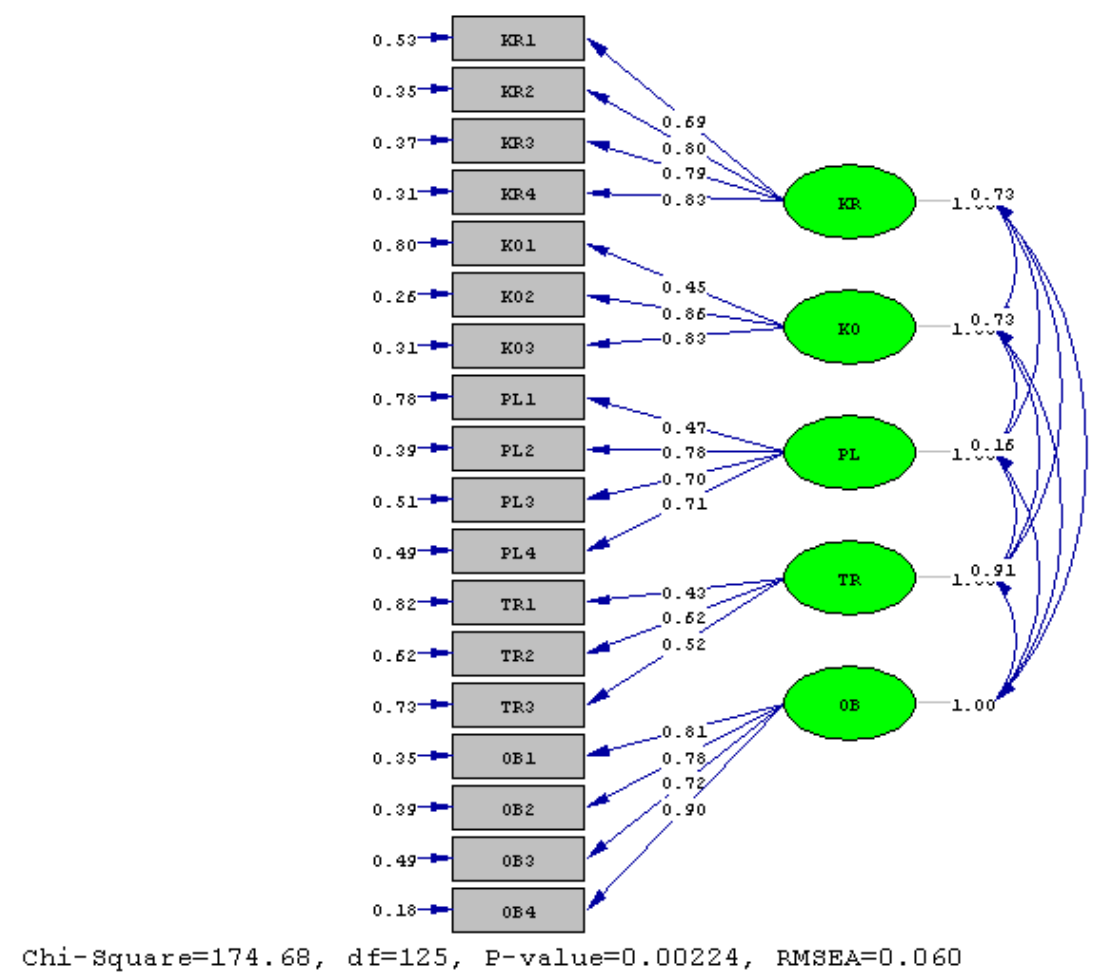

Gambar 1. Model standardized solution

Hasil-hasil pada Tabel III menunjukkan nilai muatan faktor $(\lambda)$ setiap varabel bervariasi antara 0,43 hingga 0,90 . Nilai muatan faktor ini lebih besar dari kriteria penerimaan 0,40 , serta $t$-value lebih besar dari 1,96. Sementara itu, reliabilitas konstruk dari setiap faktor bervariasi dari 0,51 hingga 0,88 . Faktor trialability mempunyai reliabilitas konstruk kurang dari kriteria penerimaan. Secara umum berdasarkan nilai-nilai muatan faktor serta reliabilitas konstruk menunjukkan bahwa variabel-variabel yang diamati mampu menjelaskan faktor-faktor yang menjadi karakteristik adopsi e-learning.

Uji kecocokan model (goodness-of-fit) menunjukkan nilai p yang sangat kecil $(0,00224)$ dan RMSEA termasuk dalam kategori good-fit (RMSEA $\leq 0,06)$. Hasil analisis ini menunjukkan terdapat kecocokan antara model yang dibangun dengan data empiris.

Hasil analisis faktor konfirmatori menunjukkan semua variabel dari setiap faktor adopsi e-learning menunjukkan hasil yang valid. Hal ini berarti bahwa variabel-variabel tersebut mampu menjelaskan setiap faktor yang dibentuk.
Hasil ini sangat penting dalam rangka mengembangkan suatu model pengukuran konstruk. Faktor keunggulan relatif diukur menggunakan empat butir pertanyaan (variabel). E-learning dapat meningkatkan produktivitas dalam pembelajaran merupakan variabel dengan nilai muatan faktor terbesar yakni 0,83 . Sementara e-learning memudahkan pelaksanaan proses pembelajaran merupakan variabel dengan nilai muatan faktor terendah yakni 0,69. Apabila dicermati masing-masing nilai muatan faktor dapat dimaknai bahwa e-learning mampu meningkatkan produktivitas dalam pembelajaran merupakan variabel yang memberikan kontribusi terbesar dalam menjelaskan konsep keunggulan relatif e-learning. Penelitian Bennett \& Bennett [10] menunjukkan bahwa hambatan utama yang dihadapi guru dalam menggunakan TIK bukan pada keterbatasan sarana TIK dan dana, tetapi lebih pada kemauan dalam menggunakan TIK dan keyakinan manfaat TIK. Keyakinan akan manfaat TIK salah satunya dapat dilihat dari keunggulan relatif yang dimiliki oleh TIK dibandingkan dengan metode sebelumnya. 
6 Journal of Information Systems, Volume 8, Issue 1, April 2012

TABEL III

RANGKUMAN HASIL ANALISIS KONFIRMATORI

\begin{tabular}{|c|c|c|c|c|c|c|}
\hline \multirow[t]{2}{*}{ Faktor $\rightarrow$} & \multirow[b]{2}{*}{ Variabel } & \multicolumn{2}{|c|}{ Validitas } & \multirow[b]{2}{*}{ Error $(\delta)$} & \multirow{2}{*}{$\begin{array}{c}\text { Reliabilitas } \\
\text { Konstruk }\end{array}$} & \multirow{2}{*}{ Keterangan } \\
\hline & & Lambda $(\lambda)$ & $t$-value & & & \\
\hline \multirow[t]{5}{*}{$\mathrm{KR} \rightarrow$} & & & & & 0,86 & Reliabel \\
\hline & KR1 & 0,69 & 7,88 & 0,53 & & Valid \\
\hline & KR2 & 0,80 & 9,85 & 0,35 & & Valid \\
\hline & KR3 & 0,79 & 9,57 & 0,37 & & Valid \\
\hline & KR4 & 0,83 & 10,31 & 0,31 & & Valid \\
\hline \multirow[t]{4}{*}{$\mathrm{KO} \rightarrow$} & & & & & 0,77 & Reliabel \\
\hline & KO1 & 0,45 & 4,57 & 0,80 & & Valid \\
\hline & $\mathrm{KO} 2$ & 0,85 & 10,55 & 0,26 & & Valid \\
\hline & KO3 & 0,83 & 10,14 & 0,31 & & Valid \\
\hline \multirow[t]{5}{*}{$\mathrm{PL} \rightarrow$} & & & & & 0,76 & Reliabel \\
\hline & PL1 & 0,47 & 4,55 & 0,78 & & Valid \\
\hline & PL2 & 0,78 & 8,49 & 0,39 & & Valid \\
\hline & PL3 & 0,70 & 7,47 & 0,51 & & Valid \\
\hline & PL4 & 0,71 & 7,54 & 0,49 & & Valid \\
\hline \multirow[t]{4}{*}{$\mathrm{TR} \rightarrow$} & & & & & 0,51 & Reliabel \\
\hline & TR1 & 0,43 & 4,31 & 0,82 & & Valid \\
\hline & TR2 & 0,52 & 5,21 & 0,52 & & Valid \\
\hline & TR3 & 0,52 & 5,30 & 0,73 & & Valid \\
\hline \multirow[t]{5}{*}{$\mathrm{OB} \rightarrow$} & & & & & 0,88 & Reliabel \\
\hline & OB1 & 0,81 & 9,98 & 0,35 & & Valid \\
\hline & OB2 & 0,78 & 9,58 & 0,39 & & Valid \\
\hline & OB3 & 0,72 & 8,44 & 0,49 & & Valid \\
\hline & OB4 & 0,90 & 11,96 & 0,18 & & Valid \\
\hline
\end{tabular}

Sejalan dengan hasil-hasil tersebut, $e$ learning sesuai dengan gaya (style) dalam kegiatan pembelajaran merupakan variabel memberikan kontribusi terbesar dalam menjelaskan konsep kompatibilitas e-learning dengan nilai muatan faktor 0,83 . Hasil penelitian Carter \& Belanger [13] menunjukkan keunggulan relatif dan kompatibilitas merupakan prediktor yang signifikan dalam mengukur niat untuk mengadopsi suatu inovasi.

Kompleksitas e-learning dijelaskan oleh variabel "pembelajaran menjadi rumit" dengan nilai muatan faktor 0,78. Penelitian Kalema, et al. [14] menunjukkan kompleksitas berpengaruh negatif terhadap prioritas siswa dalam menggunakan course management system. Hanya saja meningkatnya motivasi mahasiswa dalam pembelajaran merupakan salah satu variabel dari observability e-learning yang dapat diamati secara visual.

Kemudahan yang diberikan e-learning dengan adanya prosedur manual serta tersedianya tutorial untuk melakukan uji coba sehingga pembelajaran menggunakan e-learning menjadi semakin jelas merupakan dua variabel yang menjelaskan tentang faktor trialability e-learning. Hasil penelitian ini sejalan dengan penelitian Butler \& Sellbom (2002), di mana kepercayaan terhadap teknologi telah diidentifikasi sebagai faktor yang paling penting dalam keputusan guru apakah akan mengadposi atau tidak. Pengetahuan tentang bagaimana suatu teknologi, kesulitan dalam belajar dan waktu yang diperlukan untuk belajar muncul sebagai faktor kedua yang paling penting dalam adopsi. Kesulitan menggunakan dukungan teknologi dan manajemen muncul sebagai faktor-faktor lain yang mempengaruhi adopsi.

\section{Kesimpulan dan Saran}

Faktor keunggulan relatif mempunyai rerata tertinggi $(3,92)$, yang kemudian berturut-turut diikuti oleh faktor trialability, observability, kompatibilitas, serta faktor kompleksitas mempunyai rerata terendah $(2,99)$. Hasil ini mengindikasikan e-learning mempunyai keunggulan relatif yang lebih baik dibandingkan dengan metode pembelajaran secara konvensional serta mempunyai kompleksitas yang tidak terlalu sulit untuk dipelajari. Kompleksitas inovasi yang semakin rendah menyebabkan adopsi inovasi menjadi semakin tinggi.

Berdasarkan nilai muatan faktor serta reliabilitas konstruk ditemukan bahwa variabelvariabel yang diamati mampu menjelaskan faktorfaktor yang menjadi karakteristik adopsi $e$ learning. Kelima karakteristik e-learning dinyatakan valid untuk membangun model pengukuran adopsi inovasi e-learning. Uji fit model menunjukkan terdapat kecocokan antara model yang dibangun dengan data empiris, dengan nilai $\mathrm{p}=0,00224$ dan $\mathrm{RMSEA}=0,060$.

Perlu dilakukan penelitian lanjutan dengan mengidentifikasi lebih banyak lagi faktor-faktor yang berpengaruh dalam adopsi inovasi $e$ learning, seperti faktor lingkungan belajar serta perilaku dosen dalam mengadopsi e-learning. 


\section{Referensi}

[1] Ben Youssef, A., \& Dahmani, M. "The impact of ICT on student performance in higher education: Direct effects, indirect effects and organisational change". In The Economics of E-learning [online monograph]. Revista de Universidad y Sociedad del Conocimiento (RUSC), 5(1): 45-56, 2008. Http://www.uoc.edu/rusc/5/1/dt /eng/benyoussef_dahmani.pdf. Diakses 2 Maret 2012.

[2] Mehra, P., \& Mital, M. "Integrating technology into the teaching-learning transaction: Pedagogical and technological perceptions of management faculty". International Journal of Education and Development using Information and Communication Technology (IJEDICT), 3(1): 105-115, 2007.

[3] Usluel, Y. K., Aşkar, P., \& Baş, T. "A structural equation model for ICT usage in higher education". Educational Technology \& Society, 11(2): 262-273, 2008.

[4] Anderson, J. "ICT transforming education: A regional guide". Bangkok: UNESCO Bangkok. 2010.

[5] Almarashdeh, I.A., Sahari, N., Zin, N.A.M., \& Alsmadi, M. "The success of learning management system among distance learners in Malaysian Universities". Journal of Theoretical and Applied Information Technology, 12(2): 80-91, 2010.

[6] Šumak, B., Heričko, M., Polančič, G., \& Pušnik, M. "Investigation of E-Learning System Acceptance using UTAUT," International Journal of Engineering Education, vol. 26, no. 6, pp. 1327-1342, 2010.

[7] Rogers, E.M. "Diffusion of innovations", $\left(5^{\text {th }}\right.$ ed). New York: The Free Press. 2003.

[8] Jebeile, S., \& Reeve, R. "The diffusion of elearning innovations in an Australian secondary college: Strategies and tactics for educational leaders". The Innovation Journal, 8(4), 2003. Http://www.innovation. cc/peer-reviewed/jebeile-reeve-elearning.pdf. Diakses 23 Mei 2012.

[9] Al-Ammari, J. \& Hamad, S. "Factors Influencing the Adoption of E-Learning at UOB”, University of Bahrain. 2009. Http://uqu.edu.sa/files2/tiny_mce/plugins/file manager/files/30/papers/f82. Diakses $23 \mathrm{Mei}$ 2012.
[10] Bennett, J., \& Bennett, L.. "A review of factors that influence the diffusion of innovation when structuring a faculty training program". Internet and Higher Education, 6: 53-63, 2003.

[11] Serow, R. C., \& Zorowski, C. F. "Diffusion of instructional innovations in engineering education". Paper presented at ICEE'99, Czech Republic, Paper No. 258, 1999.

[12] Butler, D. L., \& Sellbom, M. "Barriers to adopting technology". Educause Quarterly, 2: 22-28, 2002.

[13] Carter, L. \& Belanger, F. "The utilisation of egovernment services: Citizen trust innovation and acceptance factors". Information Systems Journal, 15(1): 5-25, 2005.

[14] Kalema, M. B., Olugbara O. O., \& Kekwaletswe M. R. "The Application of Structural Equation modeling Technique to Analyse Students Priorities in Using Course Management Systems". International Journal of Computing and ICT Research, 5 (Special Issue): 34-44, 2011. http://ijcir.org/ specialissue2011/article5.pdf. Diakses 23 Mei 2012.

[15] Davis, F. D., Bagozzi, R. P., \& Warshaw, P. R. "User acceptance of computer technology: A comparison of two theoretical models". Management Sci, 35(8): 982-1002, 1989.

[16] Moore, G. C., \& Benbasat, I. "Development of an instrument to measure the perceptions of adopting an information technology innovation". Information Systems Research, 2(3): 173-191, 1991.

[17] Thompson, R. L., Higgins, C A., \& Howell, J. M. "Personal computing: Toward a conceptual model of utilization". MIS Quart, 15(1): 124-143, 1991.

[18] Taylor, S., \& Todd, P. A. "Understanding information technology usage: A test of competing models". Information Systems Research, 6(2): 144-176, 1995.

[19] Karahanna, E., Straub, D.W., \& Chervany, N. L. "Information technology adoption across time: A cross-sectional comparison of pre-adoption and post-adoption beliefs". MIS Quarterly, 23: 183-213, 1999.

[20] Hair, J. F., Jr, Black, B., Babin, B. J., Anderson, R. E., \& Tatham, R. L. "Multivariate data analysis" (6th ed.). Upper Saddle River, NJ: Prentice Hall. 2006. 